\title{
TFE3 Gene Rearrangement
}

National Cancer Institute

\section{Source}

National Cancer Institute. TFE3 Gene Rearrangement. NCI Thesaurus. Code C133697.

A molecular abnormality indicating rearrangement of the TFE3 gene. 